\title{
Istota zobowiązania wekslowego w prawie polskim, cz. II
}

\section{The Essence of Liability of Bill of Exchange in Polish Law, Part II mgr Jakub Abramowicz}

E-mail: jakub.abramowicz2@gmail.com; nr ORCID:0000-0002-0353-998X

\begin{abstract}
Streszczenie
W pierwszej części niniejszego opracowania, opublikowanej na łamach „Przeglądu Ustawodawstwa Gospodarczego” nr 2/2019 zostały przedstawione koncepcje dotyczące charakteru zobowiązania wekslowego. Niewątpliwie istota zobowiązania wekslowego była i jest przedmiotem sporu. Dlatego w drugiej części opracowania zajęto stanowisko w dyskusji dotyczącej tego zagadnienia. Podstawą rozważań są przepisy ustawy z 28.04.1936 r. — Prawo wekslowe ${ }^{1}$. W związku z tym dokonano analizy charakteru zobowiązania wekslowego i podjęto próbę sformułowania stanowiska w tym zakre- sie.
\end{abstract}

Słowa kluczowe: weksel, teorie wekslowe, indos, papiery wartościowe, jednostronna czynność prawna

\section{Summary}

In the first part of my work, I have presented a various ideas regarding the character of a bill of exchange. Undoubtedly the essence of the liability a bill of exchange was and still is a cause for dispute. That is why in the second part of this work a response has been made in this discussion. Based on the Polish law's regulations I made and analysis of the liability of a bill of exchange and made an attempt of formulation my own position on the issue.

Key words: : bill of exchange, bill of exchange theories, endorsement, securities, unilateral legal action

JEL: K150

Str. $18-26$

\section{Bibliografia}

Abramowicz, J. (2019). Istota zobowiązania wekslowego w prawie polskim (cz. 1), Przeglad Ustawodawstwa Gospodarczego, (2), 1423.

Antosiewicz M. (2018). Są ingeruje w zasady prawidlowego wypetniania weksla. http://www.rp.pl/Firma/302199974-Sad-ingeruje-wzasady-prawi-dlowego-wypelniania-weksla.html (17.11.2018).

Bühn J. (1928). O zastępczem podpisywaniu weksli. Przegląd Prawa i Administracji (3), 382.

Czarnecki, M., Bagińska, L. (2013). Prawo wekslowe i czekowe. Komentarz. Warszawa: C.H. Beck.

Doliński, A. (1925). Polskie prawo wekslowe. Poznań: Krajowy Instytut Wydawniczy.

Fenichel, Z. (1934). Istota zobowiązania wekslowego. Przegląd Prawa Handlowego, (5), 196.

Goldberger, S. (1938). Weksle zaginione. Warszawa: Drukarnia Piotr Pyz i S-ka.

Górski, A. (1925). Prawo wekslowe i czekowe. Warszawa: Księgarnia F. Hoesicka.

Grzybowski, S. (1976), Papiery wartościowe. W: W. Czachórski (red.), System Prawa Cywilnego (t. 3, cz. 2). Prawo zobowiązań - część szczegółowa. Wrocław: Zakład Narodowy im. Ossolińskich.

Grzybowski, S. (1974). W: W. Czachórski (red.), System Prawa Cywilnego (t. 1). Czesść ogólna. Warszawa: Zakład Narodowy im. Ossolińskich.

Howorka, M. (1928). Polskie prawo wekslowe i czekowe. Podręcznik do studiów uniwersyteckich, szkót handlowych i praktycznego użytku. Poznań: Główny Skład w Kole Prawników i Ekonomistów.

Ignatowicz, J. (1972). W: Z. Resich (red.), Kodeks cywilny. Komentarz (t. 1). Warszawa: Wydawnictwo Prawnicze.

Jacobi, E. (1901). Die Wertpapiere in bürgerlichen Recht. Jena: Gustav Fischer.

Janczewski, S. (1946). Prawo handlowe, wekslowe i czekowe. Warszawa: Trzaska, Evert i Michalski. 
Jastrzębski, J., Kaliński, M. (2008). Prawo wekslowe i czekowe. Komentarz. Warszawa: Wydawnictwo Prawnicze LexisNexis.

Jastrzębski, J., Kaliński, M. (2014). Prawo wekslowe i czekowe. Komentarz. Warszawa: LexisNexis.

Jastrzębski, R. (2003). Funkcje weksla w II Rzeczypospolitej. Warszawa: Liber.

Kaliński, M. (2000). Umowny charakter zobowiązania wekslowego (cz. 1). Prawo Papierów Wartościowych, (3), 13-20.

Komosa, T., Opalski, W. (1997). Prawo wekslowe. Prawo czekowe. Komentarz. Warszawa: Wydawnictwo PWN.

Koziński, M. H. (1999). Prawo wekslowe. Toruń: TNOiK „Dom Organizatora”.

Koziński, M. H. (2016). Weksle. W: A. Szumański (red.), System Prawa Prywatnego (t. 18). Prawo papierów wartościowych. Warszawa: C.H. Beck.

Krajewski, M. (2013). Charakter prawny przeniesienia posiadania. Studia Prawa Prywatnego, (3), $79-107$.

Księżak, P. (2010). Glosa do postanowienia SN z 15.01.2010 r., I CSK 355/09. Rejent, (12), 79-84.

Kunicki, A. (1977). W: W. Czachórski (red.), System Prawa Cywilnego (t. 2). Prawo własności i inne prawa rzeczowe. Wrocław: Zakład Narodowy im. Ossolińskich.

Namitkiewicz, J. (1927). Prawo handlowe, wekslowe, czekowe i upadlościowe. Warszawa: Księgarnia F. Hoesicka.

Ogiegło, L. (1995). Charakter prawny powstania zobowiązania wekslowego. Rejent, (9), 97-116.

Piasecki, K. (1997). Prawo wekslowe i czekowe. Komentarz. Bydgoszcz: Branta.

Retinger, J. (1876). Powszechna ustawa wekslowa (wraz z tekstem niemieckim) tudzież z ustawa o postępowaniu w sprawach wekslowych (opatrzo- ne licznemi orzeczeniami najwyższego sądu w Wiedniu). Kraków: Księgarnia G. Gebethnera i Sp.

Rosenblüth, I. (1936). Prawo wekslowe i czekowe. Komentarz. Kraków: Księgarnia Powszechna

Szczygielski, A. D. (1936). Prawo wekslowe i czekowe 1936. Warszawa: Bibljoteka Prawnicza.

Szpunar, A. (1937). Przekazwedlug kodeksu zobowiązań. Kraków: Druk Uniwersytetu Jagiellońskiego.

Szpunar, A. (1992). O powstaniu zobowiązania wekslowego. Przegląd Ustawodawstwa Gospodarczego, (1), 1-6.

Szpunar, A., Kaliński, M. (2003). Komentarz do prawa wekslowego i czekowego. Warszawa: LexisNexis.

Wolter, A., Ignatowicz, J., Stefaniuk, K. (2001). Prawo cywilne. Zarys części ogólnej. Warszawa: Wydawnictwo Prawnicze LexisNexis.

Wróblewski, S. (1900). Powszechna Ustawa Wekslowa wraz z innemi ustawami i rozporządzeniami odnoszacemi się do prawa wekslowego, orzeczeniami Sądów Najwyższych i przeglądem ustawodawstwa zagranicznego. Kraków: Leon Frommer.

Wróblewski, S. (1936). Prawo Wekslowe i Czekowe. Kraków: Leon Frommer.

Zöllner W. (1987). Wartpapierrecht. Ein Studienbuch, München: C.H. Beck. 